\title{
THE APPROACHES OF TURKISH PEDIATRIC DENTISTS TO THE USE OF CONE BEAM COMPUTED TOMOGRAPHY
}

\author{
TÜRKİYEDE ÇOCUK DİŞ HEKİMLERİNİN KONİK IŞINLI BİLGİSAYARLI \\ TOMOGRAFI KULLANIMINA YAKLAŞIMI
}

\author{
Dr. Öğr. Üyesi Katibe Tuğçe TEMUR* \\ Dr. Öğr. Üyesi Aslı SOĞUKPINAR** \\ Dr. Öğr. Üyesi Ömer HATİPOĞLU***
}

Makale Kodu/Article code: 4190
Makale Gönderilme tarihi; 22.10 .2019
Kabul Tarihi: 20.03 .2020

DOI : $10.17567 /$ ataunidfd.706776
K. Tuğçe Temur: ORCID ID: 0000-0001-9947-5679

Aslı Soğukpinar: ORCID ID: 0000-0002-1934-9945

Ömer Hatipoğlu: ORCID ID: 0000-0001-9947-5679

\section{ABSTRACT}

Aim: The use and indications of methods that require more radiation dose than conventional imaging methods such as Cone Beam Computed Tomography (CBCT) are still controversial. In this article, it is aimed to evaluate the frequency of the use of CBCT among Turkish pedodontists, their indications and to understand the need for training.

Materials and Methods: Two-part questionnaire in an electronic environment was applied to 210 pedodontists to evaluate sociodemographic characteristics and CBCT usage. One part of the questionnaire included questions about the demographic characteristics of pedodontists such as gender and age. In the other section, there were questions about the use of CBCT. The results of the survey were evaluated with the chi-square test. Data analysis was performed using Statistical Package for the Social Sciences version 23.0 (SPSS Inc., Chicago, II., USA).

Results: $95.4 \%$ reported that panoramic radiography and periapical radiographs were the initial radiologic methods applied in children. $75.2 \%$ of Turkish pedodontists reported that CBCT was necessary for a pediatric patient. CBCT was reported to be used most commonly in cases with cyst-tumor. $84.8 \%$ of pedodontists reported that they needed more training on CBCT.

Conclusions: Turkish pedodontists consider that CBCT is absolutely necessary and they need training on this topic. They often prefer a small FOV area in pediatric patients. They most commonly prefer CBCT in cases of cyst and tumour.

Keywords: Cone Beam Computed Tomography, Pedodontics, Child

\section{öz}

Amaç: Konik Işınlı Bilgisayarlı Tomografi (KIBT) gibi konvansiyonel görüntüleme yöntemlerine göre daha fazla radyasyon dozu gerektiren yöntemlerin çocuklarda kullanımı ve endikasyonları hala tartışmalııı. Bu makalede, Türk pedodontistleri arasında KIBT kullanım sıklığı, endikasyonlarını değerlendirmek ve eğitim ihtiyacının anlaşılması amaçlanmıştır.

Materyal ve Metod: Elektronik ortamdan 210 pedodontiste sosyodemografik özellikleri ve KIBT kullanımını değerlendiren, iki kısımdan oluşan anket uygulandı. Anketin bir bölümünde pedodontistlerin cinsiyet ve yaş gibi demografik özellikleri ile ilgili sorular vardı. Diğer bölümde, KIBT kullanımı ile ilgili sorular vardı. Tamamlanan anketler incelendi, sonuçlar ve ki- kare testi kullanılarak istatistiksel olarak analiz edildi. Veri analizi, Statistical Package for the Social Sciences 23.0 versiyonu (SPSS Inc., Chicago, II., ABD) kullanılarak gerçekleştirildi.

Bulgular: \%95,4'ü çocuk hastada ilk başvurduğu radyografi yönteminin panoramik radyografi ve periapikal radyografi olarak bildirdi. Türk pedodontistlerin \% 75, $2^{\prime}$ si çocuk hastada $\mathrm{KIBT}^{\prime}$ nin gerekli olduğunu bildirdi. KIBT' ye en sık kist tümör vakalarında başvurulduğu bildirildi. Pedodontistlerin \%84,8'i KIBT konusunda daha fazla eğitime intiyacı olduğunu bildirdi.

Sonuç:

Türk pedodontistler KIBT' yi kesinlikle gerekli görmektedirler ve bu konuda eğitime intiyaç duymaktadır. Çocuk hastada sıklıkla küçük FOV alanı tercih etmekteler. En sık kist tümör vakalarında KIBT' ye başvurmaktalar.

Anahtar Kelime: Konik Işınlı Bilgisayarlı Tomografi, Pedodonti, Çocuk

\footnotetext{
* Department of Department of Oral and Maxillofacial Radiology, Faculty of Dentistry, Kahramanmaraş Sütçü Imam University, Kahramanmaraş

** Department of Pediatric Dentistry, Faculty of Dentistry, Kahramanmaraş Sütçü Imam University, Kahramanmaraş.

*** Department of Restorative Dentistry, Faculty of Dentistry, Sutcu Imam University, Kahramanmaraş.
}

Kaynakça Bilgisi: Temur KT, Soğukpınar A, Hatipoğlu Ö. Türkiyede Çocuk Diş hekimlerinin Konik Işınlı Bilgisayarlı Tomografi Kullanımına Yaklaşımı. Atatürk Üniv Diş Hek Fak Derg 2020; 30: 406-11

Citation Information: Temur KT, Sogukpinar A, Hatipoglu O. The approaches of Turkish pediatric dentists to the use of Cone Beam Computed Tomography. $J$ Dent Fac Atatürk Uni 2020; 30: 406-11. 


\section{INTRODUCTION}

Although CBCT was originally used in dentistry for implants, it is increasingly used in all branches of dentistry, including pediatric practices. ${ }^{1,2}$

On the other hand, the high radiation dose of CBCT compared to conventional dental radiography limits its use in pediatric dentistry. ${ }^{3,4}$ Pediatric cases are more sensitive to the risk of ionizing radiation, so more attention should be paid to imaging techniques. ${ }^{5,6}$ The pediatric patient is more likely to be harmed owing to rapid tissue growth, the possibility of DNA harm and a longer life expectancy compared to an adult of 50 years of age. It is, therefore, necessary to follow the three basic principles of radiation protection, namely the rationale principle, the limitation principle, and the optimization principle. ${ }^{7}$

For example, the use of thyroid protection around the anterior neck reduces the radiation dose received by the thyroid gland and esophagus by up to one-third, regardless of large, medium and small FOVs. ${ }^{8}$ In a study, it was reported that the radiation dose to the brain and thyroid is quite high when the FOV area is large. ${ }^{9}$ There are disparate FOV areas in CBCT can be divided into large, medium and small sizes that differ from machine to machine. ${ }^{10,11}$

When imaging with $\mathrm{CBCT}$ in children and adolescents, the limited choice of FoV is the appropriate choice. ${ }^{12}$

Furthermore, the most important advantage of CBCT in pediatric patients arises from reduced dose, less screening time and requirement of less complex equipment. This reduces the anxiety in the child patient. ${ }^{13}$

When the literature is reviewed, the use of $\mathrm{CBCT}$ in a pediatric patient is still controversial. In this article, it is aimed to investigate the frequency of conic beam computed tomography among Turkish pedodontists, to evaluate its indications and to understand the need for training.

\section{MATERIALS AND METHODS}

The study was directed by Helsinki Declaration and ethical permission was taken from the Local Ethical Committee of Kahramanmaraş Sütçü Imam University For Non-invasive Clinical Trials (Registration No:18). With reference to the similar study conducted previously, the sample size was calculated as minimum 176, with an error margin of 0.05 and a confidence interval of $90 \% .^{13}$
The questionnaire was modified based on previous studies to suit pediatric dentistry by a pedodontist and a dentomaxillofacial radiologist, and the questionnaire created using Google forms was sent to participants electronically. ${ }^{14,15}$

A questionnaire consisting of two parts, which evaluated sociodemographic characteristics and CBCT usage in 210 pedodontists, was applied electronically. One part of the questionnaire included questions about the demographic characteristics of pedodontists such as gender and age. In the other section, there were questions about the use of CBCT and radiography. The sample of the questionnaire is shown in Table 1.

The completed questionnaires were examined; the results were evaluated and analyzed using the chisquare test. Data analysis was performed using the 23.0 Statistical Package for Social Sciences (SPSS Inc., Chicago, IL., USA). The probability level for statistical significance was considered as $\mathrm{p}=0.05$.

Table-1. Questionnaire form

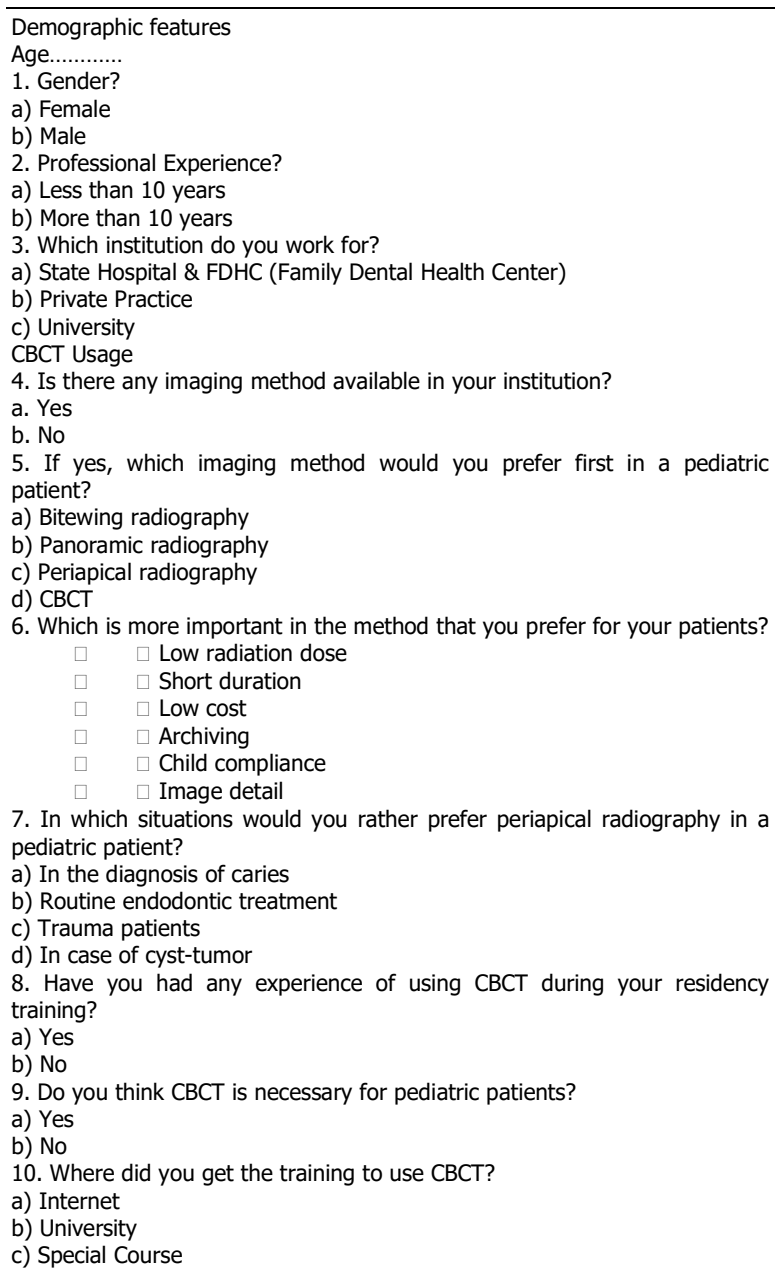

Age

Gender?

b) Male

2. Professional Experience?

a) Less than 10 years

b) More than 10 years

b) Private Practice

c) University

CBCT Usage

a. Yes

5. If yes, which imaging method would you prefer first in a pediatric patient?

a) Bitewing radiography

c) Periapical radiography

d) $\mathrm{CBCT}$

6. Which is more important in the method that you prefer for your patients? Low radiation dose

Low cost

Child compliance

Image detail

pediatric patient?

a) In the diagnosis of caries

b) Routine endodontic treatment

c) Trauma patients

8. Have you had any experience of using $\mathrm{CBCT}$ during your residency training?

9. Do you think CBCT is necessary for pediatric patients?

b) $\mathrm{No}$

10. Where did you get the training to use $\mathrm{CBCT}$ ?

b) University

c) Special Course 
TEMUR, SOĞUKPINAR, HATİPOĞLU

11. In which situations would you rather prefer $\mathrm{CBCT}$ in a pediatric patient? a) Orthodontic patient

b) Trauma patients

c) Congenital absence of teeth

d) During advanced endodontic treatment

e) In case of cyst-tumor

f) Cases with a syndrome (apert, cherubism, etc.)

g) Cases of cleft lip and palate

h) I do not prefer CBCT

12. Would you like to receive further training on $\mathrm{CBCT}$ ?

a) Yes

b) No

13. Is it necessary to extend the use of $\mathrm{CBCT}$ in specialist training?

a) Yes

b) No

14. Which FOV area do you use in a pediatric patient?

a) $\mathrm{FOV} \leq 5 \mathrm{~cm}$ (e.g. dentoalveolar, temporomandibular joint)

b) $\mathrm{FOV}=5-7 \mathrm{~cm}$ (e.g. maxilla or mandible)

c) $F O V=7-10 \mathrm{~cm}$ (e.g. area containing inferior nasal concha with mandible)

d) $\mathrm{FOV}=10-15 \mathrm{~cm}$ (e.g. area containing nasion with mandible)

e) FOV: $15 \mathrm{~cm}$ (e.g. area from the lower edge of the mandible to the vertex of the skull

\section{RESULTS}

Of the 210 pedodontists included in the study, $184(87,6 \%)$ were female and $26(12,6 \%)$ were male. $178(84,7 \%)$ pedodontists had less than 10 years of professional experience, while $32(15,3 \%)$ had more than 10 years. According to the institution, the number of pedodontists working at the university was $144(68,5 \%), 36(17,1 \%)$ pedodontists were working in private practice, and the number of pedodontists working in public hospitals was 30 (14,2\%). (Table-2)
Table 2. Distribution of Turkish Pedodontist $(n=210)$ according to gender, experience, workplace

\begin{tabular}{|l|l|l|l|}
\hline Demographical Properties & Factor & $\mathrm{N}$ & $\%$ \\
\hline \multirow{2}{*}{ Gender } & Female & 184 & $\% 87,6$ \\
\cline { 2 - 4 } & Male & 26 & $\% 12,4$ \\
\hline \multirow{2}{*}{ Experience } & $<10$ years & 178 & $\% 84,1$ \\
\cline { 2 - 4 } & $>10$ years & 32 & $\% 15,2$ \\
\hline \multirow{3}{*}{ Workplace } & Public & 30 & $\% 14.3$ \\
\cline { 2 - 4 } & Private & 36 & $\% 17.1$ \\
\cline { 2 - 4 } & University & 144 & $\% 68,6$ \\
\hline
\end{tabular}

95.4\% reported that panoramic radiography and periapical radiographs were the initial radiologic methods applied in children. $75.2 \%$ of Turkish pedodontists reported that $\mathrm{CBCT}$ was necessary for a pediatric patient. CBCT was reported to be used most commonly in cases with cyst-tumor. The second most common indication was found as orthodontic reasons. $84.8 \%$ of pedodontists reported that they needed more training on CBCT.

$42.9 \%$ of Turkish pedodontists reported that they had experienced $\mathrm{CBCT}$ use during their specialty training. $80 \%$ reported that they received $\mathrm{CBCT}$ training at university. $84.8 \%$ expressed that they needed more training on CBCT and $85.7 \%$ stated that this training should be expanded in university education.

Table 3. (Pearson's $x 2$ tests)

\begin{tabular}{|c|c|c|c|c|c|c|c|c|c|c|c|}
\hline \multirow{2}{*}{ Questions } & \multirow{2}{*}{ Answers } & \multicolumn{2}{|c|}{ Gender } & \multirow{2}{*}{$\mathrm{p}$-value } & \multicolumn{2}{|c|}{ Experience } & \multirow{2}{*}{$\mathrm{p}$-value } & \multicolumn{3}{|c|}{ Workplace } & \multirow{2}{*}{$\mathrm{p}$-value } \\
\hline & & Male & Female & & $<10$ & $>10$ & & State & Private & University & \\
\hline \multirow[b]{2}{*}{ Q4 } & Yes & $11.5 \%$ & $88.5 \%$ & \multirow{2}{*}{0.055} & $85.6 \%$ & $14.4 \%$ & \multirow{2}{*}{0.057} & $14.4 \%$ & $17.3 \%$ & $68.3 \%$ & \multirow[b]{2}{*}{0.63} \\
\hline & No & $0.0 \%$ & $100.0 \%$ & & $0.0 \%$ & $100 \%$ & & $0.0 \%$ & $0.0 \%$ & $100 \%$ & \\
\hline \multirow{3}{*}{ Q5 } & Periapical radiography & $6.3 \%$ & $93.8 \%$ & \multirow{3}{*}{0.06} & $85.4 \%$ & $14.6 \%$ & \multirow{3}{*}{0.65} & $18.8 \%$ & $14.6 \%$ & $66.7 \%$ & \multirow{3}{*}{0.31} \\
\hline & Panoramic radiography & $16.7 \%$ & $83.3 \%$ & & $85.4 \%$ & $14.6 \%$ & & $12.5 \%$ & $20.8 \%$ & $66.7 \%$ & \\
\hline & Bitewing radiography & $12.4 \%$ & $75.0 \%$ & & $75.0 \%$ & $25.0 \%$ & & $0.0 \%$ & $12.5 \%$ & $87.5 \%$ & \\
\hline \multirow{3}{*}{ Q7 } & In the diagnosis of caries & $7.1 \%$ & $92.9 \%$ & \multirow{3}{*}{0.36} & $75.0 \%$ & $25.0 \%$ & \multirow{3}{*}{0.06} & $10.7 \%$ & $17.9 \%$ & $71.4 \%$ & \multirow{3}{*}{0.10} \\
\hline & Routine endodontic treatment & $14.8 \%$ & $85.2 \%$ & & $88.9 \%$ & $11.1 \%$ & & $11.1 \%$ & $13.0 \%$ & $75.6 \%$ & \\
\hline & Trauma patients & $13.0 \%$ & $87.0 \%$ & & $87.0 \%$ & $13.0 \%$ & & $26.1 \%$ & $26.1 \%$ & $47.8 \%$ & \\
\hline \multirow{2}{*}{ Q8 } & Yes & $13.3 \%$ & $86.7 \%$ & \multirow{2}{*}{0.07} & $84.4 \%$ & $15.6 \%$ & \multirow{2}{*}{0.91} & $24.4 \%$ & $17.8 \%$ & $57.8 \%$ & \multirow{2}{*}{0.21} \\
\hline & No & $11.7 \%$ & $88.3 \%$ & & $85.0 \%$ & $15.0 \%$ & & $6.7 \%$ & $16.7 \%$ & $76.7 \%$ & \\
\hline \multirow{2}{*}{ Q9 } & Yes & $15.2 \%$ & $84.8 \%$ & \multirow{2}{*}{0.06} & $86.1 \%$ & $13.9 \%$ & \multirow{2}{*}{0.35} & $16.5 \%$ & $12.7 \%$ & $70.9 \%$ & \multirow{2}{*}{$<0.00$} \\
\hline & No & $3.8 \%$ & $96.2 \%$ & & $80.8 \%$ & $19.2 \%$ & & $7.7 \%$ & $30.8 \%$ & $61.5 \%$ & \\
\hline \multirow{3}{*}{ Q10 } & University & $10.3 \%$ & $89.7 \%$ & \multirow{3}{*}{0.065} & $85.9 \%$ & $14.1 \%$ & & $15.4 \%$ & $15.4 \%$ & $69.2 \%$ & \\
\hline & Internet & $27.3 \%$ & $72.7 \%$ & & $81.8 \%$ & $18.2 \%$ & 0.74 & $18.2 \%$ & $18.2 \%$ & 63.6 & $<0.03$ \\
\hline & Special Course & $0.0 \%$ & $100.0 \%$ & & $100.0 \%$ & $0.0 \%$ & & $100.0 \%$ & $0.0 \%$ & $0.0 \%$ & \\
\hline (1) & Yes & $10.1 \%$ & $89.9 \%$ & ד0 & $88.8 \%$ & $11.2 \%$ & 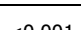 & $13.5 \%$ & $12.4 \%$ & $74.2 \%$ & $1000 ?$ \\
\hline Q12 & No & $20.0 \%$ & $80.0 \%$ & 0.07 & $16.7 \%$ & $83.3 \%$ & $<0.001$ & $33.3 \%$ & $50.0 \%$ & $16.7 \%$ & $<0.03$ \\
\hline & Yes & $12.2 \%$ & $87.8 \%$ & & $86.7 \%$ & $13.3 \%$ & & $14.4 \%$ & $15.6 \%$ & $70.0 \%$ & \\
\hline Q13 & & & & 0.67 & & & 0.06 & & & $0.0 \%$ & 0.055 \\
\hline & No & $0.0 \%$ & $100.0 \%$ & & $50.0 \%$ & $50.0 \%$ & & $50.0 \%$ & $50.0 \%$ & & \\
\hline & $\mathrm{FOV} \leq 5 \mathrm{~cm}$ & $6.1 \%$ & $93.9 \%$ & & $84.8 \%$ & $15.2 \%$ & & $6.1 \%$ & $24.2 \%$ & $69.7 \%$ & \\
\hline & $\mathrm{FOV}=7-10 \mathrm{~cm}$ & $8.3 \%$ & $91.7 \%$ & & $91.7 \%$ & $8.3 \%$ & & $8.3 \%$ & $16.7 \%$ & $75.0 \%$ & \\
\hline 014 & $F O V=5-7 \mathrm{~cm}$ & $11.5 \%$ & $88.5 \%$ & 0.055 & $82.7 \%$ & $17.3 \%$ & 0.74 & $21.2 \%$ & $13.5 \%$ & $65.4 \%$ & $<0.03$ \\
\hline Q14 & $F O V=10-15 \mathrm{~cm}$ & $66.7 \%$ & $33.3 \%$ & & $83.3 \%$ & $16.7 \%$ & & $0.0 \%$ & $16.7 \%$ & $83.3 \%$ & \\
\hline & $\mathrm{FOV}=15 \mathrm{~cm}$ & $12.4 \%$ & $87.6 \%$ & & $100.0 \%$ & $0.0 \%$ & & $50.0 \%$ & $0.0 \%$ & $68.6 \%$ & \\
\hline
\end{tabular}


$49.5 \%$ preferred $\mathrm{FOV}=5-7 \mathrm{~cm}$ (eg. maxilla or mandible) and $31.4 \%$ preferred $\mathrm{FOV} \leq \% 5 \mathrm{~cm}$ (eg. dentoalveolar, temporomandibular joint).

It was determined that $70.9 \%$ of the pedodontists who think that is necessary for a pediatric patient was employed in a university. $(p<0.00)$ It was found that $69.2 \%$ of the pedodontists, who received specialty training from a university worked in a university. $(p<0.003)$

There was a significant difference between CBCT training needs and years of professional experience. $(p<0.001) 88.8 \%$ of those who stated that they needed more training on CBCT had less than 10 years of professional experience. A significant difference was found between the need for CBCT training and the institution worked. It was found that $70 \%$ of those who stated that they needed more CBCT training worked in a university.

There was a significant difference between the preferred FOV area and the institution worked. $(p<0.003)$ It was found that $83 \%$ of those who prefer $\mathrm{FOV}=10-15 \mathrm{~cm}$ worked in a university.

\section{DISCUSSION}

There are studies on the use of radiology applications in children and adolescents in different countries. However, there are few studies in the literature investigating the use of $\mathrm{CBCT}$ in the pediatric population. $11,16,17,18,19$ In this article, it is aimed to investigate the frequency of conic beam computed tomography among Turkish pedodontists, to evaluate its indications and to understand the need for training.

It was determined that $68.5 \%$ of the pedodontists included in the study worked at the university and $87.6 \%$ were women. This can be explained by the fact that the pedodontists working in universities are more sensitive about scientific studies and that the pedodontics department is often preferred by women.

In our study, $74.3 \%$ of pedodontists reported that CBCT was necessary for a pediatric patient. The fact that $70.9 \%$ of pedodontists who believe that $\mathrm{CBCT}$ is necessary in a pediatric patient work in a university is explained by the treatment of advanced cases in these institutions. $(p<0.00)$ In a similar study, it was reported that $87.1 \%$ of pedodontists resorted to three-dimensional imaging. A study conducted in the USA reported that $80.3 \%$ of endodontists, $85.7 \%$ of orthodontists, and $78.7 \%$ of surgeons used $\mathrm{CBCT} .{ }^{20}$
The indications for CBCT vary according to general dentistry and subspecialties. In a study conducted by Carter et al. on CBCT indications of oral surgeons, it was reported that jaw-facial pathologies and dental implants (95\%), evaluation of supernumerary teeth $(91.9 \%)$ and sinus lifting planning $(81.4 \%)$ were among the most common indications. $^{21}$

Some studies have shown that dental surgeons use CBCT most frequently during the implant planning stage. $^{15}$

In another study evaluating the attitudes of orthodontists towards CBCT, it was reported that this method was used for the detection of impacted teeth $(80.9 \%)$ and for evaluation of oral and craniofacial anomalies such as cleft lip and palate (57.4\%). ${ }^{14}$

In an additional study evaluating CBCT indications in pediatric and adolescent cases, the most common indication was found to be canine and adjacent tooth resorption in an abnormal location. However, when they categorize children by age, it is stated that the second most common indication is cyst and tumour, especially in the $16-18$ age group. ${ }^{17}$ In some similar study on the pediatric patient group, $\mathrm{CBCT}$ has been used most frequently to evaluate tooth localization and tooth resorption. ${ }^{11,16}$

In this study, it was reported that pedodontists most commonly used CBCT in cases of the cyst and/or tumor. We think that different results were obtained due to age distribution differences, age distribution and in the pediatric patients included in the study and differences in the indication contents in the questionnaires applied.

In this study, $42.6 \%$ of Turkish pedodontists reported that they had experience of using CBCT during their specialty training. $85.1 \%$ reported that they needed more training on CBCT.

$88.8 \%$ of those who stated that they needed more training on CBCT had less than 10 years of professional experience $(p<0.001)$. This can be explained by the fact that those with less professional experience are more willing to improve themselves.

On the other hand, $70 \%$ of those who stated that they needed more training on СBCT are employed in a university. This can be explained by the fact that universities are education and research centers. In another study conducted among endodontists, it was reported that scientific meetings and congresses organized by associations and universities helped to encourage further training. The Internet was also 
TEMUR, SOĞUKPINAR, HATİPOGLUU

considered another resource for updating information. $^{21}$

In another study among endodontists, scientific meetings and congresses organized by associations and universities were reported to help promote further education. The Internet was also considered as another resource used by endodontists to update their knowledge. $^{21}$

In this study, it was reported that pedodontists in Turkey most commonly gained information on CBCT from universities as well as through the Internet and private courses.

In a studies on the use of CBCT in pediatric dentistry, the smallest FOV $(5 \times 5,5)$ was the most commonly used FOV in clinics. ${ }^{16,18,19}$

In this study, however, $48.5 \%$ of pedodontists preferred $\mathrm{FOV}=5-7 \mathrm{~cm}$ (eg. maxilla or mandible) and $30.7 \%$ preferred $\mathrm{FOV} \leq 5 \mathrm{~cm}$ (eg. dentoalveolar region or temporomandibular joint). There was a significant difference between the preferred FOV area and the institution worked. $(p<0.003)$. Jacop et al reported that the big FOV is preferred for surgical planning and follow-up. ${ }^{16}$

It was found that $83 \%$ of those who prefer FOV $=10-15 \mathrm{~cm}$ are employed in a university. The possible reason that pedodontists generally prefer a small FOV area in a pediatric patient can be explained by the fact that they seek to take images using a lower radiation dose. In universities that are centers of education and research, a larger FOV area may be needed.

\section{CONCLUSIONS}

Turkish pedodontists consider that $\mathrm{CBCT}$ is absolutely necessary and they need training on this topic. They often prefer a small FOV area in pediatric patients. They most commonly prefer CBCT in cases of cyst and tumour.

\section{Acknowledgements}

The authors declare that there were no other contributors involved in this work.

Conflicts of interest statement

The authors declare no conflict of interest.

\section{REFERENCES}

1. European Commission. Radiation protection 172: evidence based guidelines on cone beam CT for dental and maxillofacial radiology. Luxembourg: Office for Official Publications of the European Communities. 2012; http://ec.europa.eu/energy/n uclear/radiation_protection/doc/publication/172.pd f (accessed 9 July 2013).

2. Kapila S, Conley RS, Harrell WE Jr. The current status of cone beam computed tomography imaging in orthodontics. Dentomaxillofac Radio/ 2011;40:24-34.

3. Okano T, Harata $Y$, Sugihara $Y$, Sakaino $R$, Tsuchida R, Iwai K, Seki K, Araki K. Absorbed and effective doses from cone-beam volumetric imaging for implant planning. Dento Maxillo Facial Radiol 2009;38:79-85.

4. Silva MA, Wolf $U$, Heinicke $F$, Bumann A, Visser $H$, Hirsch E. Cone-beam computed tomography for routine orthodontic treatment planning: a radiation dose evaluation. Am J Orthod Dentofac Orthop: Off Publ Am Assoc Orthodontists, Constituent Soc, Am Board Orthod 2008;133:641-45.

5. Theodorakou C, Walker A, Horner K, Pauwels R, Bogaerts R, Dds RJ, Consortium SP. Estimation of pediatric organ and effective doses from dental cone beam CT using anthropomorphic phantoms. Brit J Radiol 2012;85:153-60.

6. Little MP. Heterogeneity of variation of relative risk by age at exposure in the Japanese atomic bomb survivors. Radiat Environ Bioph 2009;48:253-62.

7. Aps JK. СBCT in pediatric dentistry: Overview of recent literatüre. Eur Arch Paediatr Dent 2013;14:131-40.

8. Qu X, Li G, Zhang Z, Ma X. Thyroid shields for radiation dose reduction during cone-beam computed tomography scanning for different oral and maxillofacial regions. Eur J Radiol 2012;81:376-80.

9. Marcu M, Hedesiu M, Salmon B, Pauwels R, Stratis A, Oenning ACC, Cohen ME, Jacobs R, Baciut $M$, Roman $R$. Estimation of the radiation dose for pediatric $\mathrm{CBCT}$ indications: a prospective study on ProMax3D. Int J Paediatr Dent 2018;28:300-09.

10. Harris D, Horner K, Gröndahl K, Jacobs R, Helmrot E, Benic GI, Bornstein MM, Dawood A, Quirynen M. E.A.O. guidelines for the use of diagnostic imaging in implant dentistry 2011. A consensus workshop organized by the European Association for 
TEMUR, SOĞUKPINAR, HATİPOGLU

Osseointegration at the Medical University of Warsaw. Clin Oral Implants Res 2012;23:1243-53

11. Hidalgo-Rivas JA, Theodorakou C, Carmichael $F$ et al. Use of cone beam CT in children and young people in three United Kingdom dental hospitals. Int J Paediatr Dent 2014;24:336-348.

12. Pauwels R, Beinsberger J, Collaert B, Theodorakou C, Rogers J, Walker A, Cockmartin L, Bosmans H, Jacobs $R$, Bogaerts $R$. Effective dose range for dental cone beam computed tomography scanners. Eur J Radiol 2012;81:267-71.

13. TUIK Statistical Data in Turkey. http://www.tuik.gov.tr. Accessed March 13, 2018.

14. Gecgelen Cesur M, Yilmaz A, Ozer T. Knowledge and attitudes towards digital radiography and CBCT among orthodontists. Biomed Res 2016;27: 959-64.

15. Shetty S, Castelino R, Babu S, Laxmana A, Roopashri K. Knowledge and attitude of dentists towards cone beam computed tomography in mangalore-a questionnaire survey. Austin J Radiol 2015;2:1016.

16. Jacop WG, Acker V, Marters LC et al. CBCT in pediatric dentistry a retrospective observational study. Clinical oral investigatıons 2016:20;1003-10.

17. Hajem S,Brogardh RS, Nilsson $M$ et al. CBCT os Swedish children and adolescents at an oral maxillofacial radiology department. A survey of request and indications. Acta odontologia Scandinavica 2019;1-8.

18. Giray FE1, Peker S1, Yalcinkaya SE2, Kargul B1, Aps J3. Attitudes and knowledge of pediatric dentists' on digital radiography and cone-beam computed tomography. J Pak Med Assoc 2019;69:205-210.

19. Van Acker JW, Martens LC, Aps JK. Cone-beam computed tomography in pediatric dentistry, a retrospective observational study. Clin Oral Investig 2016;20:1003-1010.

20. Setzer FC, Hinckley N, Kohli MR, Karabucak B. A survey of cone-beam computed tomographic use amongst endodontic practitioners in the United States. Journal of Endodontics 2017;43:699-704.

21. Carter JB, Stone JD, Clark RS, Mercer JE. Applications of $\mathrm{CBCT}$ in oral and maxillofacial surgery:an overview of published indications and clinical usage in United States academic centers and oral and maxillofacial surgery practices. J Oral Maxillofac Surg 2016;74:668-79.

\section{Yazışma Adresi}

Katibe Tuğçe Temur, DDS, Phd

Department of Department of Oral and Maxillofacial Radiology, Faculty of Dentistry, Kahramanmaraş Sütçü Imam University, Kahramanmaraş, Turkey.

E-mail: tugcetemur@ksu.edu.tr 